\title{
SOCIAL PERCEPTION OF TIME, DISTANCE AND HIGH-SPEED TRANSPORTATION
}

\author{
Olivier Klein
}

\begin{abstract}
The aim of this paper is to throw light on the link between high speed means of transportation - especially the TGV - and the present-day temporal structures of the society. The first part describes how the industrial time is born of the industrial capitalism and its conceptions of the work. This model changes but is still very topical, regarding certain important aspects of the contemporary socioeconomic structures. Nevertheless, this permanence can't explain the whole current evolutions. The second part shows how the high speed travel behaviors - considering only professional purposes - reveal also some mains breaks with the model of industrial time. Third part looks into the model of the fragmented time, which would appear gradually surimposed to the industrial time. Finally, the fourth part presents the figures of high speed as an opportunity and high speed as a necessity. This dual reading of the ways to deal with the distance with high speed means of transportation, appears adapted to the double temporal structure which prevails today.
\end{abstract}

\section{Key-words:}

Social time, production system, high speed uses, travel behaviors. 


\section{Introduction}

A means of transportation is a human invention used to move people and goods from one geographical point to another. Clearly, the roles assigned geographical areas and the mobility of people and goods are highly interdependent, however, a further characteristic of transportation is its speed, i.e. there is also a temporal dimension to transportation that is expressed precisely by the time required for the trip and the speed of movement. The purpose here is to discuss how modern means of high-speed transportation, particularly high-speed trains, constitute an answer to the time structures prevalent in society today.

Whether one looks at quantum physics or at human activities and how society is organised, it is today accepted that time is not a universal value. Right from the very start of modern sociology, Emile Durkheim (1912), in The elementary forms of religious life, presented time as a collective creation, "a category of thought" resulting from life in society (Sue, 1992). Since then, the concept of "social time" has been developed, notably through the acknowledgement of the multiplicity of rhythms and time structures in societies (Pronovost, 1996).

This social concept of time has enabled historians to analyse the processes involved in structuring and differentiating time through the ages. Jacques Le Goff (1960) notes the emergence in medieval cities of a "time of merchants" that gradually gained its autonomy from the "time of the Church", in response to the necessities of the activities of the bourgeois class. Jacques Attali (1982, p. 132) organises the history of time during the Middle Ages with the appearance of a time of the cities and the 
merchants, the "time of weights"1, better suited to measuring work than the primitive "time of the Gods" that it replaced. This dichotomy would now seem to be more or less confirmed by all medieval historians (Leduc, 1999, p. 140 and following pages).

The first part of this presentation will attempt to describe how industrial capitalism produced an industrial time compatible with its inherent concept of work. We shall see that this model has evolved, but remains highly relevant to certain important aspects of contemporary socio-economic structures. That being said, the continued relevance of the concept does not mean it takes into account all of the current changes. The second part of this presentation shows how the behaviour involved in high-speed travel (we will take into account only professional travel) reveals a number of fundamental departures from the industrial-time model. In the third part, a new model is proposed, that of fragmented time which may gradually replace the former model. Finally, the fourth part, using the notions of high speed as an opportunity and high speed as a necessity, presents a double interpretation of distance management in the context of high-speed transportation, suited to the double time structure prevalent today.

\section{Industrial time}

\section{The time of industrial capitalism}

In a paper published in 1967, Edward P. Thompson analysed in detail the progressive adaptation of time perception to the necessities of industrial capitalism. He showed the difference between "task-structured" time, relatively characteristic of pre-

1 Attali's french expression is "le temps des corps". It suggests a parallel between pair of scales weights used for the commercial activities, which became socialy dominent, and clock weights used to time measurement. This combined history of time and of its tools of measurement is a way 
industrial society, and the continuous notion of time that slowly came to dominate. He explained the process in terms of a major change in society where the most significant aspect is the development of strong demand for non-specialised work capacities in industry.

The indispensable synchronisation of tasks in increasingly complex production processes gradually led employers to purchase intervals of very unqualified work rather than pay for the execution of each task taken individually. The goal was to gain control over the timing of the various operations and the total time of production. This necessity meant that a universal unit of time was required and that time measurement had to be easy. The spread of clocks and watches constituted an important technological event perfectly suited to the needs of the period. Edward Thompson (1967) notices that, as could be expected, it was precisely at the time when the industrial revolution required greater synchronisation of work that the use of clocks and watches expanded rapidly.

The purchase of work on an hourly basis also implied that the workers accept a strict time discipline. This requirement was reinforced by the growing complexity of production tasks and the resulting need to coordinate operations. However, this discipline did not come at all naturally for a population accustomed to structuring its time along very different lines. The resistance and the changes involved in this adaptation had a profound impact on the lifestyles of individuals and, of course, on the overall social organisation accompanying this upheaval.

This evolution in the structure of work time brought with it a major paradox. It implied an adaptation "of all the time patterns in social life" (Pronovost, 1996, p. 32) to the demands of industrial production. But, at the same time, it produced a clear 
separation between work time, sold to the employer, and "free" time, even though the latter was for a long period strictly limited to the necessities of reproducing the productive force. Consequently, at the very moment that "work defined the pivotal interval in industrial societies around which all other social times were reorganised" (idem), it also lost its absolute character derived from the perpetual cycle of agricultural work and became the basis of a trade and the object of conflicts of interest.

That being said, work did not become less important. On the contrary, within industrial society, it became one of the essential values for both the dominant and the working classes. Major pressure did appear, however, based on the separation between work time and time "for living", to reduce the first and increase the second (Tonneau, 1998). Gerhard Bosch (1999) made clear the point to which progress in this field was made possible and encouraged by gains in productivity during the 1900s. Along other lines, Jacques Attali (1982, p. 190), in designating free time (evenings and week-ends) as the legal vent for the violence required to regulate society, underlined the profound link between work time and free time. The dynamics underlying free time and work time are therefore intimately related.

In short, industrial time is, first of all, a commodity, work that is traded for a price. Because it is marketed, it was gradually structured to become continuous and non-differentiated, in order to be measured. This time is used exclusively for work in the framework of a contract. All other activities must take place before or afterwards and, consequently, the time patterns of social life are organised around the time devoted to work. Work and its duration, the central values of society, lie at the heart of the conflict between those who sell their work and those who buy it. The significant reduction in the time spent at work and the increase in its cost over a century progressed in step with the increases in productivity. 


\section{Industrial time is still a valid concept}

The industrial-time model, as perceived through historical analysis, must, of course, be updated. To start, work is much more diversified. The increasing complexity of production processes and the development of services have progressed in step with the development, through experience or schooling, of a wide array of competencies within the workforce. Job markets have long reflected the significant degree of work division.

The perception of work has also changed greatly due to the general increase in free time, in revenues and in the qualifications of workers. Rudolph Rezsohazy (1986) suggested that the cultural upheaval of the 1960s was also the sign of "the shift from a puritan view to an instrumental view of work" (p. 44). By that, he meant that work has become a means of self accomplishment and is no longer simply a moral obligation and a material necessity. It should also be noted that this adaptation to a more individualistic ideology is more a sign of work's renewed importance as a social value than of its decrease (Morin and Cherre, 1999).

This transformation of work into a means of self accomplishment has progressed in step with the emergence of organisational modes of production providing individuals with greater autonomy. The transformation is also manifested in demands for flexibility and control over work rhythms and schedules. These demands are clearly in line with the flexibility requirements of business managers, but viewpoints and interests are nonetheless particularly divergent at the present time (Thoemmes and de Terssac, 1997).

One of the current types of production system can be rapidly described, using the term "flexible taylorism" (Durand, 1991), as a form of quantitative flexibility provided to a large extent by the labour force. In this particular context, the dominant defensive 
strategies (Leborgne and Lipietz, 1992) generally block any change in the types of relations between work time and free time. Employees have relatively little control over their work. Any changes are most often very directive in nature and finally cause more frustration than fulfilment, resulting in true social suffering (Dejours, de Bandt and Dubar, 1995). The self accomplishment of individuals is consequently all the less likely to occur during work because it is very difficult to use work time to build strong social identities.

Even if actively employed women is not a recent phenomenon (Schweitzer, 2002), the increasing number of working women accentuates the difficulties to reconcile work time and time "for living". Women not only demand more equality at work, but they also wish a higher control of the rythms of the personnal or domestic life (Méda, 2001). This tension is very usually managed by separating the field of work and the field of personnal life: women avoid - or are excluded from - jobs that imply a lot of availability, they work part time, they don't have access easily to in-service trainings... (Boltanski and Chiapello, 1999, p. 301).

In spite of the constraints in terms of work rhythms and schedules caused by the flexibility requirements of the production sector (Tremblay and Villeneuve, 1997), "free" time continues to be organised around work time. Interference between the two remains limited to the social factors determining how the free time is spent (Gershuny, 1992). Nonetheless, the simple, quantitative increase in the time not spend at work means this time can become the basis for the processes involved in building collective identities (Yonnet, 1999). Flexible taylorism is therefore a vector for some change in the separation between work and social life. But by dealing with the constraints unilaterally, with social life always submitting to work, flexible taylorism blocks any fundamental changes in the separation. 
The industrial-time model is currently undergoing important changes, but it nonetheless remains consistent and relevant to the economic behaviour dictated primarily by competitive pressure on prices, according to the distinction made by Pierre Veltz (1993) between this competitive mode and competition excluding the cost factor. The strategies targeting faster return on capital are consequently based on the main characteristics of industrial time, i.e. continuity, non-differentiation and a market value expressed by interest rates. The pressure on work productivity that is generally the result is based in large part on a linked perception that work resources are not specific enough to become irreplaceable. Industrial time corresponds to a flexible form of taylorism that work sociologists admit is the most prevalent in the French economy (Linhart, Linhart and Malan, 1998).

\section{High-speed cracks in the model}

In spite of its relevance, the industrial-time model is not sufficient to explain all the changes in contemporary society. A number of comprehensive prospective-analysis efforts have pointed out its limits. To start, the "computer bomb" has been criticised by Paul Virilio (1998) because it places our action in a general context of real time that cancels out the past, present and future. In a more optimistic vein, Manual Castells (1996,) came to the same conclusion and announced the dawn of the "network society", based on a new social structure whose basic orientation, still in the development stage, is to do away with time as an organised sequence of events. Without a doubt, there is something going on with time.

The purpose of this section is to illustrate how high-speed trains in France (TGVs) and the social behaviour they make possible reveal a number of cracks in the industrialtime model. Taking into account travel for professional reasons, this section first 
examines the development of "pseudo-ubiquitous" mobility, based on round trips in a single day. It then goes on to show that this type of behaviour implies a blurring of the border between professional and private life. Finally, it deals with the notion of urgency that is becoming a standard mode of operation in society today.

The observations carried out by the Laboratoire d'Économie des Transports (LET) on TGV lines running from Paris down to south-eastern France (Bonnafous, 1987) and to the Atlantic (Klein and Claisse, 1997) confirm the trend to a reduction in the duration of trips. What would previously have been longer business trips are now turning into one-day round trips on the condition that the time each way does not exceed three hours. This is because one-day trips are considered a valid solution for business only if it is still possible to put in almost a full day (at least six hours).

Under these conditions, one-day round trips are becoming the dominant form of travel because they are deemed the best solution (by avoiding the need to spend the night in a hotel, they simplify the organisation of trips and reduce the cost) and simply the way to do business by frequent users of the TGV (Chevallier, 1989). It may be noted that this "standardised" nature is not specific to the TGV. More generally, it concerns the most advanced means of communication and was noted, at a very early stage in their development, for mobile telephones (Carre, 1996, Moeglin, 1996). This social standard is therefore expressed by individual behaviour, but also through collective modes of organisation in the business world and finally through urban policies that make the possibility of one-day round trips to other major cities one of the standard elements in the services that a city must make available to its inhabitants (Klein, 2001).

In terms of how time is used, these travel habits initially tend to disregard the actual travel time because the goal is to move from point to point without impinging on 
the time devoted to the main activities2. It is in this sense that we may speak of "pseudo-ubiquity". In the process, these habits become part of a time structure that is very different than the continuity of the industrial-time model.

However, the non-integration of the travel time remains partial. A round trip between Paris and Lyons, taking into account the travel at each end, means the traveller must include at least five hours of total travel time in the day. It is by organising activities that the traveller attempts to improve the "elimination" of travel time. Maurice Chevallier (1989) described how frequent users of the TGV manage their daily schedules as a single unit, juggling their professional obligations, travel requirements and family life as best as possible. These observations are largely confirmed by the initial users of mobile telephones consulted by Francis Jaureguiberry (1996). This form of organisation, which attempts to preserve both the time required for work and one's private life, reinforces the interdependence between the two domains (work and nonwork) that industrial time so clearly separated.

The persons interviewed by Maurice Chevallier also stressed the fact that, due to the shorter travel times and the possibility of organising one-day round trips, the gain is not only in terms of time. In that travel has become much simpler, it requires less preparation and decisions can be made at the last minute. The TGV therefore injects greater flexibility in the management of distance and makes it possible, for example, to

2 The fact that the SNCF (French national train company) initially fell prey to the mirage of ubiquity is very revealing. Its first advertising for the TGV ("Spend less time spending time") and the interior furnishing and decoration of the first TGV wagons, rather Spartan, signified that the time spent travelling was considered wasted. It was only after a number of years in running the highspeed lines that the company became aware of the danger of neglecting the time spent by its clients in its trains. The more comfortable furnishings in the latest generations of wagons, the efforts to develop on-board services and the latest advertising campaign ("Take the time to spend less time") all indicate a reversal of the initial attitude and current efforts to make the most of the travel time. 
respond more easily to an urgent request requiring travel or to improve monitoring of a remote activity.

However, the greater flexibility provided by high-speed transportation is not without its drawbacks. Similar to the users of mobile telephones, users of the TGV mention the increase in pressure that the possibility of easy travel brings to bear on them. The observations made by Alain Tarrius (1992) concerning the travelling "professional elite" reveal situations of real stress, even anguish on the part of people confronted with the uncertainty of the rhythms governing their lives. In that the protection provided by distance no longer exists, it is more difficult to decline requests. However, it is the systematic nature of a feeling of urgency that people confronted with modern communication tools mention (Jaureguiberry, 1998, concerning telephones, Chevallier, 1989, concerning the TGV).

The feminine version of those constraints can be easily imagined. Women who take in charge family time are kept away from - or have difficulties in occupying - jobs that imply a high pressure of temporal flexibility. Thus they suffer from a limited acces to the work market or from deteriorated conditions of life.

Again, it is not only the fact that distance no longer protects. The level of performance offered by these tools makes it possible to set up forms of organisation in which the standard operating mode is characterised by immediate action and even urgency. The perception of time as a continuous phenomenon is again disrupted. It is through these fairly serious disruptions in essential characteristics that the capacity of analysis on high-speed business travel to reveal cracks in industrial time becomes clear. 


\section{Fragmented time}

Edward Thompson (1967) stressed that the time models that he analysed were never dominant at a given time or in a given society. The historian described the process by which the time of industrial capitalism became not only the time of work, but also the time around which all other activities were organised. He insisted on the long duration of these transformations which lasted over a century simply for the most intense period. He also showed that "task-oriented" time, his term to designate the time structure that dominated society before the development of industrial capitalism, continued to mould many activities of social life throughout the 1800 s and even afterwards.

Jacques Attali (1982) showed how the various time structures overlapped, piled up and, of course, competed with each other. The rates of change for the various elements making up these time structures (time-measurement techniques, organisation of production techniques, social organisation, etc.) are always very different. Though historical evolution is perceived as a succession of times, from the "time of the Gods" to the "time of weights", the "time of machines" and finally the "time of codes", the passage from one to the next is never precisely dated. The chronological mile stones are very imprecise. This is due to the fact that the establishment of "a new perception of time [...] is always preceded by the invention of the instruments required for its measurement and followed by the appearance of a new master of social organisation. [...] Conversely, the theory for each new time structure would seem never to be totally formulated until the end of the given structure's domination" (p. 247). Under these conditions, it is understandable that "one time structure never eliminated another, each new structure was overlaid on top of the previously dominant structure" (p. 247-248). This long shift from one time structure to another with significant overlap is largely 
confirmed by historians (Leduc, 1999, p. 150-151) and the sociologist Roger Sue (1995, p. 136-140). We may therefore imagine that a new time structure, not yet totally formulated but already distinct, will come into being along side industrial time.

\section{The new time structures of the production system}

The pressure to intensify the use of time is an essential component of capitalism. The pressure would not seem to be less strong today than during the $1800 \mathrm{~s}$. A number of authors have even noted that this tendency has resulted recently in an "exacerbation" of the phenomenon. In the economic sphere, for example, the result of the combination of non-cost competition, i.e. the capacity to react quickly and to innovate, and costbased competition is not simply to reduce lead times. It also tends to structure time in a binary manner where it is important not only to provide the product as fast as possible, but above all to provide it "just in time", i.e. first, for example, in the targeted market niche.

The "strategic", yet initially money-losing investments required by many activities in the "new economy", the race to patent caused by the pressure to innovate (Mercure, 1995), or the industrial niche strategies set up by automobile manufacturers (Freyssenet, 2000) are all illustrations of a binary time structure. Financial innovation reacts in the same manner to a system that grants a considerable advantage to the company capable of analysing the slightest change in regulations and marketing a new and well targeted product. Generally speaking, real time and the absence of nonproductive time constitute the law imposed by the financial powers that be on the economic sector (Mongin, 2000, using the title of a book by André Orléans).

The conditions in which labour can be mobilised obviously cannot escape this increasingly fragmented time structure. For example, professional careers are no longer 
organised with the long term in mind. Previously, an apprentice trained for his profession on the job and at the same time learnt the customs and habits of the profession in contact with the older workers. He took on a recognised social identity and spent most of his professional life in the same factory, slowly working up to rungs (though often very few) of an essentially stable management ladder (De Coninck, 1994). Today, what with entire companies restructuring and fleeting opportunities, a typical career is often made up of sequences lasting a few years or even just a few months. Special training courses for a given task, better suited to the new conditions, develop competencies that the traditional transmission of experience can no longer provide. Frédéric de Coninck calls this phenomenon "management in the present tense" (1995, p. 241).

This fragmentation also concerns daily rhythms in a general context of efforts to eliminate non-productive time (Cohen, 1999). Frédéric de Coninck (p. 267) analyses how the sharply increasing demands in terms of synchronisation within production processes have confronted operators and their immediate superiors with an inextricable mix of short-, mid- and long-term time structures. For example, Philippe Mosse and James Arrowsmith (1998) illustrated this situation in a Franco-British comparison of time structures for hospital personnel. Finally, the interviews of company executives carried out by Paul Bouffartigue and Mélanie Bocchino (1998) also reveal, in a general context of work overloads, the irregularity of the tasks that must be executed during "rush jobs". The fragmentation of time is therefore another manner of analysing the diversification of social rhythms that are becoming increasingly difficult to regulate collectively.

The available studies on the reduction of work hours in a number of western countries clearly show the tensions that emerge. If we neglect the set of problems 
having to do with work sharing, it would appear, in general, that the trade-off is between the reduction in the number of work hours and enhanced flexibility of those work hours (Tonneau, 1998). A number of authors have noted the fairly clear trend among employees - especially executives - to prefer longer week-ends and vacation rather than a reduction in the average time spent working each day (Anxo et alii., 1998; Tremblay and Villeneuve, 1998, for example). This desire is often analysed as the result of concerns dealing with the protection of a person's personal time, when confronted with the uncertainty of the normal work schedule of a common work day. It is also the sign of a renewed vigour of the values associated with "free time" (Dumazedier, 1988) and it is not independant of renewed process of social stratification (Gershuny, 2000 and the survey analysis from Coulangeon, Menger and Roharik, 2002).

About the protection of a person's personal time, teleworking, which is generaly characterized by increasing work period to the detriment of the personnal life, seems to be problematic (Steward, 2000). Less pessimistic, the conclusion from a survey by Tietze and Musson (2002) insists on the fact that such new forms of work organization strongly involve both spheres, domestic and professional.

Other strategies for adaptation to flexible schedules have been observed on the part of professional categories required to remain highly available. For example, Paul Bouffartigue and Mélanie Bocchino (1998, p. 45) stress the strong link between the availability that is required of company executives and the autonomy granted in managing their time. They highlight the fact that these two aspects "are part of the social identity of executives and the distinct nature of their job". The requirement in terms of availability may be interpreted as a form of integration of the company's time constraints within the personal time schedule. 
Going beyond the specificities of any given situation, a far-reaching rearrangement of the relations between work time and free time has emerged. Where industrial time established a clear distinction, new contemporary rhythms would seem to make possible major overlapping and interaction (Pronovost, 1996, p. 42).

The dual structure proposed here, including both industrial time and fragmented time, is the means to avoid an overly simplistic view in which the work time/free time dichotomy is considered a part of the industrial past (Breedveld, 1996, for example).

\section{The fragmented time of autonomy and integration}

In light of the above, we may attempt to list the areas where contemporary perceptions of time differ from the industrial-time model. The first concerns the blurring of the distinction set up at the start of industrial capitalism between work time and the time devoted to social life.

A second divergence from the industrial-time model concerns the disruption of time continuity. The fragmentation of time and the mixing of rhythms are images that are frequently mentioned in efforts to describe productive organization (Zucchermaglio and Talamo, 2000) or people's activity. They are also direct references to the "multiscalar" perceptions of living spaces (Ollivro, 2000). Concerning time dimensions, Frédéric de Coninck placed great importance on this phenomenon in the field of productive activities, however, it is even reinforced by the vast increase in interaction between work and personal activities. In certain situations, as yet still very specific, concerning in particular highly qualified jobs, the combination of different factors reinforces these changes to the point of appearing to constitute a return to the "taskoriented" work that Edward Thompson attributed to pre-industrial societies. In fact, these situations, which perhaps constitute the ultimate development of the current 
trends, are considerably different than those noted in traditional societies, in particular because they are characterised by systematic rationalisation of the use of time.

Finally, the increase in uncertainty is the third differentiating element in the contemporary time structure compared to the time of industrial capitalism. In this respect, the breakdown of strict time regulation and the resulting enhanced competitive pressure play an essential role. In this context, the systematic efforts to increase flexibility are as much a response to the uncertainty as a factor in its increase.

It may be noted that uncertainty is not limited to the economic sector. Political analysts commonly express the opinion that "democracy is simply the institutionalisation of uncertainty" (Santisot, 1994, p. 1083). More generally, Anthony Giddens, in The Consequences of Modernity (1990), develops the idea of a constant examination and revision of social practices in light of the new information made available on those practices. In this framework, references to the past and continuity (in the form of calls to respect traditions) are weakened and the making of the future becomes uncertain. A fairly similar idea may be noted in the work of historian François Hartog (1995) who suggested that we are entering a phase where the past and the future are invoked simply to assuage our fears in the present.

The contemporary perception of fragmented time is therefore not free of contradictions. It is based in particular on an organisational model that comprises not only these contradictions, but also the means to manage them. Highly polymorphic in nature, it nonetheless offers a certain regularity in that it combines two opposite tendencies, the first toward integration, the second toward autonomy (Klein, 2001). The strong pressure to integrate the various components of a production unit may well include demands in terms of reactivity. On the other hand, the autonomy of each of the components encourages the mobilisation of their own resources, often developed over 
the long term. Whatever the case may be, fragmented time would seem to be clearly distinguishable from industrial time, even with respect to the major dynamics underlying these time structures. Luc Boltanski and Ève Chiapello (1999, p. 236) notice that the traditionnal separation between the sphere of the factory ans the domestic sphere desappear progressively.

Jacques Attali has also suggested the emergence of a "time of codes" that will supersede the "time of machines". It is certainly too early (and presumptuous) to clearly identify a "time of codes" and the fragmented time described above. However, heuristic comparisons are perhaps a possibility. This is particularly the case for the notion of "specific time" developed by Jacques Attali. On the basis of observations in the fields of contemporary physics and biology, he has suggested that a possible basis for the "time of codes" could be the existence, parallel to the "objective and abstract universal time" established by the "time of machines", of a "time specific to each system" (Attali, 1982, p. 260). Though caution is required with this analogy, it is possible to see how the dual nature of the emerging time structure could constitute one of the primary foundations of the autonomy/integration organisational model by combining within each unit of the production system an "autonomous" time specific to each component and a collective time with an integrating role in the structure as a whole.

\section{Social times and mobility}

There is obviously a close relation between the time structures of contemporary society and the behaviour in terms of mobility that may be observed within that society. This is because mobility brings into play both time and space. As a result, it is a constitutive part of the social perceptions of time that prevail during any given period because to exist, a society must organise the meetings of its members in both time and 
space. Following the presentation of the cracks in the industrial-time model revealed by the observation of people taking part in high-speed travel, this last section will attempt to analyse the rationales behind the use of speed that prevail today, basing that analysis on the two contemporary time structures discussed above.

However, before making any distinctions, we must stress that both industrial time and fragmented time, each with its own specificities, express the increasing pressure to intensify the use of time. The development of a new form of transportation such as the TGV, whose primary social justification is speed, thus constitutes an event that may be interpreted using either of the dominant perceptions of time. With this in mind, two rationales concerning the use of speed are proposed, the first where speed is considered an opportunity (based essentially on the notion of industrial time) and the second where speed is considered a necessity (expressed in terms of fragmented time).

\section{The industrial rationale of speed as an opportunity}

The TGV is perceived, first of all, as a means to "gain time". This expression indicates that time is a resource and can be saved. It also implies that each moment "gained" can be put to use. According to this rationale, the use of high-speed transportation would seem to refer to industrial time, where time is continuous and can be exchanged. In this continuous time framework, high speeds are immediately profitable. They are perceived as an opportunity to reduce travel time, which may be considered one of the costs of travel. Within this rationale and for business trips, the cost of travel is simply a business expense. A reduction in the travel time is therefore a means to improve competitiveness. In this sense, speed as an opportunity serves above all to meet the demands of economic activities for which competitiveness is essentially based on cost. Consequently, it can also be linked to flexible taylorism. 
These efforts to reduce costs probably explain the massive transfer from planes to trains that took place when the TGV was put into service, on the part of business travellers employed by industrial companies. On the basis of studies carried out by the Laboratoire d'Économie des Transports (LET), it is clear that, both during the 1980-85 period for the first TGV line (south-east) and during the 1989-93 period for the second TGV line (Atlantic), for the given population segment, TGV traffic increased significantly whereas total travel (all modes) remained virtually stable. Following the increase in train speeds, the travel price and time factors were modified according to the notion of the overall cost of travel. Without falling into the trap of comparing flexible taylorism and industrial activities, it is, however, not surprising to see industrial companies react significantly to modified cost factors.

In addition to the shift in transportation modes to the least costly, a general consequence of a reduction in transportation costs is a widening of markets. High-speed trains were no exception and the phenomenon was observed and analysed in the field of certain specialised services when the TGV started operation between Paris and Lyons (Buisson, 1986). However, the conclusion of the study showed that certain companies in Lyons, which had seized the opportunity provided by the TGV to offer their services on the Parisian market, were starting to wonder how best to organise their physical setup. In that high-speed transportation makes it possible to envision both types of configuration, the questions raised highlight the point that a further result of the opening of markets is greater fluidity in determining where to locate activities.

The perception of speed as an opportunity is part of a rationale attempting to profit from the time gained (Klein, 1995). Distance is considered an operating constraint among others and decisions are made, in part, on the cost of travelling that distance, where speed is a factor in that cost. This possible decision process therefore implies that 
the motivating activity is not fundamentally dependent on the maximum performance of the transportation system. Other configurations are possible, including longer transportation times, that do not exclude the existence or the main characteristics of the activity under consideration.

A few typical examples may help in better understanding the last point. It is speed as an opportunity that is producing an effect when the circulation of people between two units in the same company is modified following the arrival of the TGV, and at the same time the attributions of each site and the overall organisation of the company are not modified. It is again the notion of opportunity at work when a sales representative or a person providing technical assistance decides to expand their operating zone without modifying customer relations. It is always a question of opportunity when a company in Paris selects a service that is better suited to its needs or less expensive from a supplier located in a provincial city, but accessible via a high-speed train link, rather than from its habitual subcontractor who is located closer, but whose service offers less.

By presenting extremely simple situations, the examples mentioned above show that speed as an opportunity is simply a theoretical image of the use of high-speed transportation, just as industrial time and flexible taylorism are simply theoretical images of contemporary social times and of organisational configurations of the production system. The brief examples mentioned above should be understood as archetypes that can help to throw light on one of the rationales behind the use of highspeed transportation rather than as actual examples of real situations.

This is because these situations in which speed does not produce any organisational change in production or in the execution of the activity that motivates the travel can only be fictions is as much as the organisation and the use of time and space cannot be separated. We may suggest, in order to take into account the inseparability, 
considering speed as an opportunity as a characteristic of situations in which an organisation can integrate travel as a cost among its parameters.

\section{The fragmented time of speed as a necessity}

The double nature (best solution and social standard) of professional travel in the form of one-day round trips has already been pointed out. This context is highly favourable to the use, in the internal workings of organisations, of the "easy travel" made possible by high-speed transportation. Rather than schedule far in advance the onsite services of a distant expert, those services may be available "on request" and scheduled on short notice. Rather than have units, set up in different cities and operating in different geographical zones, each carry out the same tasks, companies can achieve scale economies by having each unit specialise in a specific function for all the geographic zones, while ensuring coordination of activities through frequent meetings.

It is thus possible to imagine many examples of organisational systems based on the capacity of the TGV to reduce the importance of travel times and, consequently, of distances. These organisational systems constitute for companies a means to adapt to the uncertainty of their environment. But implementation of such systems profoundly transforms the way distance can be managed. The essential solidarity thus established between the geographically separate units makes high-speed transportation absolutely necessary to ensure correct operation of the company as a whole. In this sense, speed as a necessity is characteristic of organisations based on the denial of distance.

Speed as a necessity may thus be interpreted as a component in an exacerbated process of intensifying the use of time. It is the sign of a certain reality in which travel time is not only reduced, but where the remainder has no social value because it is integrated by organisations and individuals (e.g. for the latter, via arrangements 
affecting both the professional activities and private life). Speed as a necessity therefore clearly refers to the major characteristics used to describe fragmented time.

However, the denial of distance is also consistent to a large extent with the organisational model for autonomy and integration. The territorial grounding of a production unit (Zimmerman, 1998) may be considered a means to preserve its capacity to produce specific resources (Colletis and Pecqueur, 1993). In this sense, territorial grounding constitutes a degree of autonomy. High-speed transportation is one of the conditions making it possible to reconcile autonomy with the pressure to integrate in a company with many sites.

\section{Conclusion}

In the framework of an analysis combining fragmented time and the autonomy/integration organisational model, speed as a necessity takes place along side speed as an opportunity to fill out the analysis tools for contemporary social times.

It should be noted that this dual structure in the use of high-speed transportation owes a great deal to the analysis of Maurice Chevallier (1989). In the first chapter of his report (p. 5), he distinguished "two types of TGV effect".

- "The capacity of the TGV (speed and frequency) to cause a different form of mobility due not only to the frequency (more trains available), but above all to the types of travel (round trips in a half day, unplanned trips) and the new function (possibilities that were not previously available);

- A simple improvement (essentially a gain in time), without any qualitative change in the type or function of travel, nor a change in schedules (between work and free time)." 
In light of these definitions, the links between the "TGV-cause" and speed as a necessity, on the one hand, and those between the "TGV-improvement" and speed as an opportunity, on the other, become clear. The contribution of this paper is to bring together these two images of TGV use and more general analysis systems. The industrial and fragmented social times, and to an even greater extent flexible taylorism and the autonomy/integration principle, have been defined in a manner that is totally independent of the transportation sector. Using these tools, it is possible to refine the analysis of the rationales behind the use of high-speed transportation and, above all, to derive meaning from an analysis in terms of opportunity and necessity. In return, the analysis of the social uses of high-speed transportation may make it possible to view differently the role of technical communication objects in the transformation processes affecting production territories and social organizations. In particular, it may contribute to adress the issue of the renewal of the social inequalities in the current phase of globalization and to understand somes inequalities due not only to income, but also on production membership (“metropolitan work” vs "banal work”, Klein, 2003) or on social membership (see for instance the women's specific difficulties to insert their own life constraints into a logic of speed as a necessity).

\section{Bibliography:}

Anxo D., Boulin J.-Y., Lallement M., Lefèvre G. and Silvera R. (1998) 'Recomposition du temps de travail, rythmes sociaux et modes de vie. Une comparaison France -Suède', Travail et Emploi (74) : 5-20.

Attali J. (1982) Histoires du temps. Paris : Fayard, Le livre de poche, coll. Biblio/Essais, $318 \mathrm{p}$.

Bonnafous A. (1987) 'The régional impact of the TGV', Transportation 14 (2): 127137.

Boltanski L. and Chiapello E. (1999) Le nouvel esprit du capitalisme. Paris : Gallimard, coll. nrf essais, 843 p. 
Bosch G. (1999) 'Le temps de travail : tendances et nouvelles problématiques', Revue internationale du travail 138 (2) : 141-162.

Bouffartigue P. and Bocchino M. (1998) 'Travailler sans compter son temps ?: Les cadres et le temps de travail', Travail et Emploi (74) : 37-50.

Breedveld K. (1996) 'Post-fordist leisure and work', Loisir et société 19 (1) : 67-90.

Buisson M.-A. (1986) Effets indirects du T.G.V. et transformations du tertiaire supérieur en Rhône-Alpes, Lyon : Laboratoire d’Économie des Transports, coll. Études \& Recherches, $87 \mathrm{p}$.

Carré D. (1996) 'Contribution à l'analyse du processus d'institutionnalisation des techniques mobiles dans le champ de la communication d'entreprise', Technologies de l'Information et Société 8 (2) : 189-207.

Castells M. (1996) The rise of the network society. Oxford: Blackwell, 594 p.

Chevallier M., with collaboration of Couturier B. (1989) La redistribution du temps et de l'espace des usagers fréquents du TGV à Lyon et à Valence : De l'effet TGV à l'outil $T G V$, Research report for the french Ministère de l'Equipement, Bron : ARCADES, 142 p.

Cohen D. (1999) Nos temps modernes. Paris : Flammarion, coll. Essais, 161 p.

Colletis G. and Pecqueur B. (1993) 'Intégration des espaces et quasi-intégration des firmes: vers de nouvelles rencontres productives', Revue d'Économie Régionale et Urbaine (3) : 489-508.

de Coninck F. (1994) 'Le temps raccourci : quand les changements prennent de vitesse le temps d'une vie', Gérer et comprendre - Annales des Mines (june). Paper reprint in Problèmes économiques (2396), 28 septembre 1994 : 22-27.

de Coninck F. (1995) Travail intégré, société éclatée. Paris : Presses Universitaires de France, coll. Le sociologue, 289 p.

Coulangeon Ph., Menger P.-M. and Roharik I. (2002) 'Les loisirs des actifs: un reflet de la stratification sociale’, Economie et Statistique (352-353) : 39-55.

Dejours Ch., de Bandt J. and DuBAR C. (1995) La France malade du travail, Bayard, Paris, 207 p.

Dumazedier J. (1988) Révolution culturelle du temps libre: 1968-1988. Paris: Méridiens Klincksieck, coll Sociétés, 312 p.

Durand J.-P. (1991) 'Travail contre technologie' in Jean-Pierre Durand et FrançoisXavier Merrien, Sortie de siècle - La France en mutation. Paris : Vigot, pp. 33-75.

Durkheim E. (1912) Les formes élémentaires de la vie religieuse : Le système totemique en Australie. Paris: Alcan. English translation by Fields K. E. (1995) The Elementary Forms of the Religious Life. New-York: The Free Press, 464 p.

Freyssenet M. (2000) 'Un ou plusieurs modèles industriels ?', in Freyssenet M., Mair A., Shimizu K. and Volpato G., Quel modèle productif? Trajectoires et modèles industriels des constructeurs automobiles mondiaux, pp. 19-65. Paris : La Découverte, coll. Recherche.

Gershuny J. (1992) 'La répartition du temps dans les sociétés post-industrielles', Futuribles (may-june) : 215-226. 
Gershuny J. (2000) Changing Times: Work and Leisure in Postindustrial Society. Oxford : Oxford University Press, 304 p.

Giddens A. (1990) The consequences of modernity, Stanford (CA): Stanford University Press, 200p.

Hartog F. (1995) 'Temps et histoire : Comment écrire l'histoire de France ?', Annales Histoire, Sciences Sociales (6, november-décember) : 1219-1236.

Jauréguiberry F. (1996) 'De l'usage des téléphones portatifs comme expérience du dédoublement et de l'accélération du temps', Technologies de l'Information et Société 8 (2) : 169-187.

Jauréguiberry F. (1998) 'Télécommunication et généralisation de l’urgence’, Science de la société (44) : 83-96.

Klein O. (1995) 'Du rôle des villes dans la constitution du réseau à grande vitesse : entre nécessité et valorisation', in Laboratoire d'Economie des Transports, Villes et TGV - actes des entretiens Jacques Cartier (Lyon, 8-10 décembre 1993), pp. 267-274. Lyon : Laboratoire d'Economie des Transports, coll. Etudes \& Recherches (5).

Klein O. (2001) Les horizons de la grande vitesse : le TGV, une innovation lue à travers les mutations de son époque, Thèse de Doctorat es sciences économiques. Lyon : Université Lumière-Lyon 2, 310 p. Electronic edition at the following adress: http://theses.univ-lyon2.fr/bases/detail_theses.php?titre=299.

Klein O. (2003) 'Le travail métropolitain : un outil géographique pour révéler l'usage sélectif de la grande vitesse’, L’espace géographique (2) : 133-127.

Klein O. and Claisse G., with collaboration of Pochet P. (1997) Le TGV-Atlantique : entre récession et concurrence. Lyon: Laboratoire d'Economie des Transports, coll. Etudes \& Recherches (7), 163 p.

Leborgne D. and Lipietz A. (1992) 'Flexibilité offensive - flexibilité défensive : deux stratégies sociales dans la production des nouveaux espaces économiques’, in Benko G. and Lipietz A. (eds), Les régions qui gagnent - Districts et réseaux: les nouveaux paradigmes de la géographie économique, pp. 347-377. Paris: Presses Universitaires de France, coll. Economie en liberté.

Leduc J. (1999) Les historien et le temps: Conception, problématiques, écritures. Paris : Le Seuil, coll. Point Histoire, 328 p.

Le Goff J. (1960) 'Au Moyen-Âge : Temps de l’Eglise et temps du marchand', Annales E.S.C. XV (3) : 417-433.

Linhart D., Linhart R. and Malan A. (1998) 'Syndicats et organisation du travail : un rendez-vous manqué', Sociologie et sociétés XXX (2), autumn, 14 p. Electronic edition at the following adress: http://www.erudit.org/erudit/socsoc/v30n02/index.html, the 28th july 1999

Mackenzie A. (2001) 'The Technicity of Time: From 1.00 oscillations/sec to 9,192,631,770Hz', Time \& Society 10, (2, september) : 235-258.

Méda D. (2001) Le temps des femmes : pour un nouveau partage des rôles. Paris: Flammarion, coll. Essais, 199 p.

Mercure D. (1995) Les temporalités sociales. Paris: L’Harmattan, coll. Logiques sociales, $175 \mathrm{p}$. 
Mœglin P. et alii (1996) 'La mobilité, entre ubiquité et omniprésence - Eléménts de problématique', in France-Télécom-CNET Actes des séminaires Action Scientifique, "Communication mobile professionnelle" (6, may) : 14-43.

Mongin O. (2000) 'Les révolutions du temps : à propos de Manuel Castells, Daniel Cohen, André Orléans et quelques autres’, Esprit (1, january) : 105-125.

Morin E. M. and Cherré B. (1999) 'Les cadres face au sens du travail', Revue française de gestion (126, november-décember) : 83-93.

Mossé Ph. and Arrowsmith J. (1998) 'Les temps de travail dans les hôpitaux en France et au Royaume-Uni : Des temporalités emboîtées’, Travail et Emploi (77) : 67-77.

Ollivro J. (2000) L'homme à toutes vitesses : De la lenteur homogène à la rapidité différenciée. Rennes: Presses Universitaires de Rennes, coll. Espaces et Territoires, $179 \mathrm{p}$.

Pronovost G. (1996) Sociologie du temps. Paris/Bruxelles, De Boeck Université, coll. Ouvertures sociologiques, $183 \mathrm{p}$.

Rezsohazy R. (1986) 'Les mutations sociales récentes et les changements de la conception du temps’, Revue Internationale des Sciences Sociales (107) : 37-52.

Santisot J. (1994) 'A la recherche des temporalités de la démocratisation', Revue française de Sciences Politiques 44 (6) : 1079-1085.

Schweitzer S. (2002) Les femmes ont toujours travaillé : une histoire du travail des femmes au XIXe et XXe siècles. Paris : Editions Odile Jacob, coll. Histoire, 330 p.

Steward B. (2000) 'Changing Time: The meaning, measurement and use of time in teleworking', Time \& Society 09 (1, march) : 57-74.

Sue R. (1992) 'Aux origines de la sociologie des temps sociaux', L'année sociologique 42, pp. 283-297.

Sue R. (1995) Temps et ordre social. Paris : Presses Universitaires de France, coll. Le sociologue, $320 \mathrm{p}$.

Tarrius A. (1992), Les fourmis d'Europe: Migrants riches, migrants pauvres et nouvelles villes internationales. Paris: L'Harmattan, coll. Logiques sociales, 207 p.

Tietze S. and Musson, G. (2002) 'When "Work” meets "Home”: Temporal flexibility as lived experience’, Time \& Society 11 (2, september) : 315-334.

Thoemmes J. and de Terssac G. (1997) 'La négociation du temps de travail et les composantes du référentiel temporel’, Loisir et société 20 (1) : 51-72.

Thompson E. P. (1967) 'Time, work and industrial capitalism', Past and Present (38, december) : 56-95.

Tonneau D. (1998) 'Création et temps de travail : vingt ans de perspectives', Réalités industrielles (november) : 22-26.

Tremblay D.-G. and Villeneuve D. (1997) 'Aménagement et réduction du temps de travail : réconcilier emploi, famille et vie personnelle’, Loisir et société 20 (1) : 107157.

Tremblay D.-G. and VILLENEUVE D. (1998) 'De la réduction à la polarisation des temps de travail : des enjeux de société’, Loisir et société 21 (2) : 399-416. 
Veltz P. (1993) 'D'une géographie des coûts à une géographie de l'organisation; Quelques thèses sur l'évolution des rapports entreprises/territoires', Revue Economique, (4, july) : 671-684.

Virilio P. (1998) La bombe informatique. Paris : Galilée, coll. L’espace critique, 159 p.

Yonnet P. (1999) Travail, loisir. Temps libre et lien social. Paris: Gallimard, coll. Bibliothèque des sciences humaines, 324 p.

Zimmerman J.-B. (1998) 'Nomadisme et ancrage territorial : propositions méthodologiques pour l'analyse des relations firmes-territoires', Revue d'Économie Régionale et Urbaine (2) : 211-230.

Zucchermaglio C. and Talamo A. (2000) 'The Social Construction of Work Time: negociated time and expected time’, Time \& Society 09, (2, september) : 205-222.

Olivier Klein is a lecturer-researcher at the École Nationale des Travaux Publics de l'État, (National School of State's Public Works), Laboratoire d'Économie des Transports, (Laboratory for Transportation Economics), Address: Rue Maurice-Audin, F69518 Vaulx-en-Velin, FRANCE [e-mail: olivier.klein@entpe.fr] 